DOI https://doi.org/10.18551/rjoas.2017-11.33

\title{
EFFECT OF DIFFERENT RUBBER MARKET SYSTEM ON FARMER'S INCOME IN SOUTH SUMATRA PROVINCE, INDONESIA
}

\author{
Husin Laila*, Yulius, Adriani Dessy, Antoni Mirza \\ University of Sriwijaya, Palembang, Indonesia \\ *E-mail: elahusin2007@yahoo.co.id
}

\begin{abstract}
Indonesia is the second biggest natural rubber producer in the world; however its processed rubber has low quality and price. This is because the rubber plantation most cultivated by non estate plantation (smallholding plantation). Central government of Indonesia has developed some policies to overcome this problem and one of them is to establish the Processing and Marketing Unit of Rubber material or PMUR ('UPPB') since 2008. However until 2014 only a few farmers (around 5\%) had sold their products with PMUR and most farmers sell their products through traditional marketing channel. This study's aims are to discuss how big impact the existing of new marketing channel (PMUR) to farmer's income is. Study conducted in two districts (Banyuasin and Musi Rawas) of South Sumatera Province, which represent two kinds of marketing channels, those are the auction market system and the partenership market system. Sampling taken of 64 farmers (as respondents), represent participant and non participant of new market system. Data collection was done in April to September 2017. The result of this study shows that there are significantly different income for farmer's participants (PMUR) and non participants (non PUMR). The farmer's income at the auction system is higher (abaout $57 \%$ ) and the farmer's income at the partnership system is higher (about 64\%) than traditional marketing system. However income of both new marketing systems or PUMR (auction and partnership systems) are not significantly different.
\end{abstract}

\section{KEY WORDS}

Auction, partnership, rubber, income, processing and marketing unit.

In 2015, Indonesia was the second biggest natural rubber producer (3.2 million tones) in the world, whereas Thailand as competitor of Indonesia has higher rubber production (4.5 million tones). Total rubber area of Thailand was smaller (2.8 million hectares) than Indonesia (3.7 million hectares), because of higher rubber productivity in Thailand than Indonesia. In fact, low rubber productivity is high correlation to total area of rubber smallholding plantation, where the contribution of rubber smallholding area in Indonesia $(85 \%)$ was more than area in Thailand, $(60 \%)$. Total area of rubber plantation was the third portion, where the first and the second portions were oil palm and oil coconut plantations. However the rubber products could contribute US\$ 4.4 billions in export value and 25 to 40 percents for plantation sector's devisa (FAO, 2016).

South Sumatera Province is the biggest rubber area in Indonesia (1.3 million hectares), almost 93 percents are smallholding plantation, consist of 579,574 farm households (Plantation Government Office of South Sumatera Province, 2017).

According to Syaffendi (2015), Indonesia rubber industry has low productivity and low processed product quality, therefore in the world market, Indoensia's bargaining power was smaller than other rubber producers (Thailand, Malaysia, Vietnam and India). In local market level, farmer's share and rubber price were lower than other countries (Thailand and Malaysia), because of long market channel (Asmara and Hanani, 2012).

Central government of Indonesia has developed some policies or regulations and programs to increase the rubber quality and price by the Agriculture and Trade Ministries such as determination of the processed rubber National Standard, method of good rubber processing and marketing, and conttrolling of processed rubber quality for exporting etc. The same fact in South Sumatera Province, there are still found dominantly the low quality of processed rubber (Syarifa, Agustina and Nancy, 2013). According to Malian and Djauhari 
(1999), there are some social economic factors which influence those problems, such as: rubber factory as demand of processed rubber ('slab') has not not supported increasing of the rubber quality, there are still some brokers or wholeseller as rent seekers, and not yet formed the partnership between the rubber farmers and the crumb rubber factories

South Sumatera Government has developed some policies to overcome this problem and one of them is to establish the Processing and Marketing Unit of Rubber material (PMUR) since 2013. Until 2016 had developed 123 PMUR for seven districts as centrals of rubber producers. Each PMUR has to manage 100 hectares of rubber areas. If in South Sumatera Province has 1.2 million hectares of rubber area, so it can be formed 12,517 PMUR.

The PMUR is one of organized rubber marketing channels in South Sumatera. Basically, there are two kinds of rubber market channel, that is traditional channel and organized channel (Plantation Government Office of South Sumatera Province, 2014). Traditional channel used almost 95 percents of small farmers, and the organized channel (auction and partnership systems) used by the rest of farmers. According to Tarmizi (2014), these organized channels are able to give the higher price for rubber farmers. The auction system consist of spot auction by PMUR (“UPPB") registered in South Sumatera Plantation Government Office and forward auction by Village Unit Cooperation ('KUD') ex Smallholder Rubber Developing Program or SRDP ('PPKR') in Muara Enim and Prabumulih Districts. Whereas partnership pattern only in Musi Rawas District.

The organized channels have to produce clean and good rubber products, based on Agriculture Ministry Regulation No 38, tha is: (1) non contaminated rubber product, (2) only uses recommended rubber coagulant by Government, (3) no apply some treatments such as dipping in water, drying under sun shine during storage session, (4) the thickness of processed rubber ('slab') is no more than 15 centimeters.

Based on the fact and development of rubber market in South Sumatera, it is interested to find the explanation why there only a few of farmers who sell the processed rubber products in the organized market system are. Some studies abaut organized channel had been done in Jambi Hermansyah et. al (2014) and Tarmizi (2014). The same studies in South Sumatera had not been done yet, including to compare both kinds of organized channels (auction and partnership systems). It is interested to analyze how big different income are between traditional and organized systems, and between different market systems (auction and partnership system) in organized rubber market channel.

\section{METHODS OF RESEARCH}

This research has been done at two rubber production centers which marketing their products by organized channel of different market systems, that is Musi Rawas District (partnership system) and Banyuasin District (auction system). Selection of Musi Rawas because the partnership system is only in this district, whereas selection of Banyuasin because the auction system (in PMUR) is the most than others. Survey method choosen by using questionair as data collection method to respondents (rubber farmers, traders, and staff of PMUR as samples). Second source of research data was collected from Plantation and Trading Government Office, Association of Indonesia Rubber Enterpreneurs ("GAPKINDO") in South Sumatera Province. Firstly, selection of PMUR with most members, then used proporsionate stratified random sampling as sampling method, total respondents are 128 farmers, represent PMUR participants (64 farmers) and non PMUR participants (64 farmers). Trader sampling method use snow ball method, select 3 big rubber traders and 2 small rubber traders.

Data processed mathematically and statistically, presented by using tabulation, discussed descriptive qualitatively and quantitatively. T-test by using parametric statistics used to compare both different market channels and market systems (Jhonson, 1982): 


$$
t=\frac{\left(\bar{x}_{1}-\bar{x}_{2}\right)-\left(\mu_{1}-\mu_{2}\right)}{\sqrt{\left(s_{1}^{2} / n_{1}\right)+\left(s_{2}{ }^{2} / n_{2}\right)}}
$$

Where:

- $\mathrm{x}_{1}=$ average rubber farmer samples' income of traditional channel;

- $\mathrm{x}_{2}=$ average rubber farmer samples' income of organized channel;

- $\mathrm{s}_{1}{ }^{2}=$ variance of rubber farmer samples' income of traditional channel;

- $\mathrm{s}_{2}{ }^{2}=$ variance of rubber farmer samples' income of organized channel;

- $\mu_{1}=$ average rubber farmer population's income of traditional channel;

- $\mu_{2}=$ average rubber farmer population's income of organized channel;

- $\mathrm{n}_{1}=$ the number of rubber farmer samples of traditional channel;

- $\mathrm{n}_{2}=$ the number of rubber farmer samples of organized channel.

With decission:

- $t_{\text {hitung }} \leq t_{\text {tabel }}$ accept $H_{0:}$ means rubber farmer's income of traditional channel and rubber

- farmer's income of organized channel are different insignificantly

- $t_{\text {hitung }}>t_{\text {tabel reject }} H_{0}$ : rubber farmer's income of traditional channel is lower than rubber

- farmer's income of organized channel

\section{RESULTS AND DISCUSSION}

Market System of Traditional Channel. In this system, the farmers sell their rubber products to the rubber traders individually. There is no formal regulation in rubber transaction, all quality level of rubber can be marketed. Determined the rubber quality is only based on only water contain and non rubber ingridients in rubber products ('slab'). The farmers' bargaining position to determine rubber price depend on quality of rubber product, the amount of rubber farmer's loan to traders. However, there are some benefits of traditional system according to farmers, such as the rubber product sale frequently and regularly, such as daily, weekly or monthly depend on the farmer's wants and paid by trader at the same time, after transaction. The trader usually come to the rubber farmers.

Generally, in each village there are some small traders who buy the farmer's rubber and then sell them to the big traders as wholesellers or brokers, finally sell out to crumb rubber's factory which located in several cities or districts. Until 2016, there are 29 crumb rubber factories in South Sumatera Province, mostly in Palembang (12 units), the rest are located in Musi Banyuasin (2 units), Ogan Komering Ilir (2 units), Banyuasin (5 units), Muara Enim (4 units) and Musi Rawas (3 units).

Market System of Organized Channel with 'The Auction System'. In this system, the farmers in group (as farmer's institution) sell their rubber products to big traders in that location. The farmer's institution can be as Village Unit Cooperation ('KUD') or the Processing and Marketing Unit of Rubber material or PMUR ('UPPB'). This market system by 'KUD', firstly done by Smallholder Rubber Developing Program (SRDP) in 1980s. This system has established until now in Muara Enim District and Prabumulih City. The auction system in this location is namely forward auction system, where 'KUD' (represent farmers) sell the rubber product to big traders. 'KUD' only collect and measure the weight of rubber which are sold by farmers and keep for several days (it can be one or two weeks). During the auction, the manager of 'KUD' only determine the winner of auction (who give the highest price), and time of payment by traders to the farmers. Transaction of auction are only once for each two weeks or four weeks. Some 'KUD'make the transaction rules in auction, such as the traders have to give some guarantee and deposit some money.

Nowdays developed spot auction system, the transaction between farmers and traders (measurement the weight and payment the rubber product), has been done at short time (may be several hours). This auction can be found most districts or cities in South Sumatera Province. The participants of auction system come from South Sumatera or Jambi and North 
Sumatera. The big traders, then sell their rubber products ('slab') to crumrubber manufacturing. The rubber price based on international price

Some PMUR ('UPPB') determine the minimum price of farmer's rubber in auction market based on Dry Rubber Content (DRC) and FOB price. This price daily can be detected easily on line via SMS, by Sumbawa Plantation Research Office. Farmers estimate their rubber's DRC base on big trader's information or their experiences

Market System of Organized Channel with 'The Partnership System'. In this system, the farmers in group (as farmer's institution) sell their rubber products directly to crumb rubber factory (without the big traders in that location as mediator). This system establish only in Muara Enim District, between some PUMRs with crumb rubber factory ('PT Kirana Windu') in Musi Rawas Utara ('Muratara') District. Price determination is similar to auction system (based on DRC), however the value of DRC measured at manufacture's laboratorium by controlling farmers and PMUR's manager/staff, but it takes more time (about 3 hours). Another method is observed visually by experienced staffs, which has high accuration level (margin error is only $2 \%$ ). This method done when the rubber product enter to factory area, before weighting. However, if the seller doesn't agree so they come back to use the first method.

Farmer's Income Comparison. Income is the most indicator used to compare two different systems, so by using farmer's income of different market systems, it can conclude that the market system is better or not. Table 1 below present comparison between the farmer's income in auction or non auction system

Table 1 - The Income Difference between participant and non participant of Auction System

\begin{tabular}{lllll}
\hline \multirow{2}{*}{ Description } & Auction system & & Different Value & Percents \\
\cline { 2 - 5 } & Participant & Non participant & Nominal value & 11.00 \\
\hline Production (kg/ha/year) & 3,823 & 3,431 & 393 & 44.00 \\
Production Cost (Rp/ha/year) & $3,918,450$ & $6,980,890$ & $-3,062,441$ & 76.00 \\
Fertilizer (Rp/ha/year) & $1,181,560$ & 672,222 & 509.337 & 100.00 \\
Land rent (Rp/ha/year) & 0 & $5,015,356$ & $-5,015,356$ & 594.00 \\
Coagulant (Rp/ha/year) & 957,064 & 138,000 & 819.064 & 50.00 \\
Average Cost (Rp/kg) & 1,025 & 2,035 & $-1,010$ & 100.00 \\
Marketing cost (Rp/kg) & 350 & 0 & 350 & 15.00 \\
Product price (Rp/kg) & 8,131 & 7,084 & 1,047 & 28.00 \\
Revenue (Rp/ha/year) & $31,088,473$ & $24,302,839$ & $6,785,635$ & 57.00 \\
Income (Rp/ha/year) & $27,170,024$ & $17,321,949$ & $9,848,075$ & \\
\hline
\end{tabular}

Souce: result of farmers's questionair (2017).

Base on informtion on Table 1, participant's rubber production is higher than non participant $(11 \%)$, whereas the age of rubber tree is older (16 years) or not planted in the peak session (12 years) such as differ for non participant's rubber tree (11 years). This higher production because of plant caring by using more fertilizer $(76 \%)$. This behavior is caused the training result of extension service in farmer's group. The participant's production cost is higher the non participant's production cost, especially in coagulant cost due to applying high price recommended liquid, such as 'asam semut' rather than low price non recommended liquid, such as 'sulfat acid'. Land Rent is only charged for non participant because most farmers are only as an operators not an land owners. They use yield share (operator: owner is $40 \%: 60 \%$ ), then this share calculated as land rent. Then, there are no marketing cost for non participant, because the rubber traders come to the field and buy the farmers' rubber. Otherwise the participant has to pay ,marketing cost such as the transportation cost and management fee for PMUR (Rp350 per $\mathrm{kg}$ ). The rubber price for participant and non participant are slight different (15\%), however, the incomes are big different (more higher) because participated farmers has higher rubber production, but lower production costs than non participant. This result indicate that auction system can increase the productivity and rubber product price (as expected of the objectives of PMUR forming).

Then to test the different populations, used t test of parametric statistical. The result shows that $t$ value (13.9) is still bigger than $t$-table (2.0) in $95 \%$ confidence level. It means that reject $\mathrm{Ho}$ (zero Hipothesis) or receive $\mathrm{Ha}$ (alternative Hipothesis). Meaningly, both 
participant and non participants' incomes are different statitistically, or participant's income is higher than non participant' income of auction market system.

Next analysis, can be seen on Table 2 below, which present comparison between the farmer's income in partnership and non partnership of organized system.

Table 2 - The Income Difference between participant and non participant of Partnership System

\begin{tabular}{|c|c|c|c|c|}
\hline \multirow{2}{*}{ Description } & \multicolumn{2}{|c|}{ Partnership System } & \multicolumn{2}{|l|}{ Different Value } \\
\hline & Participant & Non participant & Nominal value & Percents \\
\hline Production (kg/ha/year) & 2,861 & 3,052 & -191 & -6.00 \\
\hline Cost Production (Rp/ha/year) & $1,367,143$ & $1,573,679$ & $-206,536$ & -13.00 \\
\hline Fertilizer (Rp/ha/yaear) & 530,488 & 711,039 & $-180,551$ & -25.00 \\
\hline Average Cost (Rp/kg) & 478 & 516 & -38 & -7.00 \\
\hline Marketing Cost (Rp/kg) & 1,000 & 0 & 1,000 & 100.00 \\
\hline Price $(\mathrm{Rp} / \mathrm{kg})$ & 10,400 & 6,179 & 4,221 & 68.00 \\
\hline Revenue (Rp/ha/year) & $29,751,614$ & $18,856,515$ & $10,895,099$ & 58.00 \\
\hline Income (Rp/ha/year) & $28,384,471$ & $17,282,836$ & $11,101,635$ & 64.00 \\
\hline
\end{tabular}

Souce: result of farmers's questionair (2017).

Based on informtion on Table 2, participant's rubber production is lower than non participant (6\%), because of higher DRC (or lower weight of wet 'slab') and lower fertilizer dosage (indicted by lower fertilizer cost). This can cause the participant's rubber price is higher than non participant (68\%). Eventhough the participant has to spend marketing cost to sell their product toh the auction system, but the much higher price of participant $(68 \%)$ are able to keep up the participant's income so that their income are still higher than non participant's $(64 \%)$. This profit difference is really significant so the partnership system is very beneficial for rubber farmers. Unfortunately, in South Sumatera Province is only 29 crumbrubber Estates who apply the partnership system.

Then to test the different populations, used t test of parametric statistical. The result shows that $t$ value (4.4) is still bigger than t-table (2.0) in 95\% confidence level. It means that reject Ho (zero Hipothesis) or receive Ha (alternative Hipothesis). Meaningly, both participant and non participants' incomes are different statitisticcaly, or participant's income is higher than non participant' income.

Next analysis, Table 3 below present comparison between the farmer's income in auction and partnership of organized system. Base on informtion on Table 3, the rubber production of partnership is lower than auction $(25 \%)$, it cause the higher DRC (or lower weight of wet 'slab') due to small frequncy of marketing (only once or twice a month). Besides that the rubber tree's age of partnership participant is older (around 25 years) than the rubber tree's age of auction participant (they are in the peak production or around 16 years). The partnership participant has lower production cost because of fertilizer cost for older rubber plant and lower coagulant cost due to lower frequence of marketing (once or twice a month). The significant difference for both marketing systems are the price (28\%) due to different DRC or different product quality (partnership's rubber product price is higher than auction's rubber product price). Finally the partenership farmer's income is higher than auction farmer's income (4\%).

Tablel 3 - The Income Difference between Partnership and Auction in Organized Market System

\begin{tabular}{|c|c|c|c|c|}
\hline \multirow{2}{*}{ Description } & \multicolumn{2}{|c|}{ Market system } & \multicolumn{2}{|c|}{ Difference } \\
\hline & Partnership & Auction & Nominal value & Percents \\
\hline Production (kg/ha/year) & 2,861 & 3,823 & -963 & -25.00 \\
\hline ProductionCost (Rp/ha/year) & $1,367,143$ & $3,918,450$ & $-2,551,307$ & -65.00 \\
\hline Fertilizer (Rp/ha/year) & 530,488 & 1,181560 & $-651,072$ & -55.00 \\
\hline Coagulant (Rp/ha/year) & 189,268 & 957,064 & $-767,796$ & -80.00 \\
\hline Average Cost (Rp/kg) & 478 & 1,025 & -547 & -53.00 \\
\hline Marketing Cost (Rp/kg) & 1,000 & 350 & 650 & 186.00 \\
\hline Price (Rp/kg) & 10,400 & 8,131 & 2,269 & 28.00 \\
\hline Revenue (Rp/ha/year) & $29,751,614$ & $31,088,473$ & $-1,336,860$ & -4.00 \\
\hline Income (Rp/ha/year) & $28,384,471$ & $27,170,024$ & $1,214,447$ & 4.00 \\
\hline
\end{tabular}

Souce: result of farmers's questionair (2017). 
Then to test the different populations, used $T$ test parametric statistical. The result shows that $t$ value $(0.65)$ is smaller than $t$-table $(2.0)$ in $95 \%$ confidence level. It means that receive Ho (zero Hipothesis) or reject $\mathrm{Ha}$ (alternative Hipothesis). Meaningly, both partnership and auction's incomes are not different statistically, or partnership farmer's income is similar to auction farme's income in organized market channel.

\section{CONCLUSION}

There are significantly income difference between participated farmer and non participated farmer in organized market channel. Meaningly, the farmers as participant of market organized has higher income than non participant of market organized.

There are not significantly farmer's income different between partnership's and auction's participants in organized market system. Meaningly, the farmers as partnership's participant in organized market system has similar to income to auction's participant in organized market system.

\section{ACKNOWLEDGEMENTS}

This paper is part of the Grant Competitive Universitas Sriwijaya Research in 2017, which has been funded this research complies with the letter of Agreement Assignment of Competitive Grants Research Universitas Sriwijaya in 2017.

\section{REFERENCES}

1. Food and Agriculture Organization. 2016. Production and Trade. Foastat.org. http://www.fao.org.

2. Plantation Government Office of South Sumatera Province. 2017. Plantation Statistic 2017. Plantation Government Office of South Sumatera Province, Palembang.

3. 2014. Pola Pengembangan Pemasaran Komoditi Karet Sumatra Selatan. Plantation Government Office of South Sumatera Province, Palembang.

4. Syaffendi, M.R. 2014. Analisis posisi karet alam Indonesia di pasar karet alam China. Thesis in Graduate School of Bogor Agriculture University, Bogor.

5. Asmara, R., \& Hanani, N. 2012. Komparasi transmisi harga karet alam Indonesia dengan Malaysia dan Thailand. Retrieved from http://nuhfil.lecture.ub.ac.id/files/2012/ 12/jurnalkaret-perhepi-nuhfil-rosihan-final2.pdf.

6. Syarifa, L.F., D.S. Agustina and C. Nancy. 2013. Evaluasi pengolahan dan mutu bahan olah karet rakyat (bokar) di tingkat petani karet di Sumatera Selatan. Jurnal Penelitian Karet, 31(2):139-148.

7. Malian $\mathrm{H}$ and A. Djauhari. 1999. Upaya perbaikan kualitas bahan olah karet rakyat. FAE: 17(2);43-50.

8. Tarmizi, A. 2014. Analisis efisiensi saluran pemasaran karet rakyat di Jambi, Studi kasus Desa Panerokan Kecamatan Bajubang Kabupaten Batanghari Provinsi Jambi.

9. Jhonson, R.R. 1982. Jhonson, R.R. 1980. Elementary Statistics (Third Editoin). Duxbury Press, California, USA.

10. Hermansyah, R., Edison and A. Arby, 2014. Analisis komparasi pendapatan usahatani karet petani yang menjual ke pasar lelang dan luar pasar lelang di Kecamatan Sakernan Kabupaten Muaro Jambi. Sosio Ekonomika Bisnis Jurnal, 17(2): 21-31. 